\title{
Analiza przepływu płynów złożowych w skałach zbiornikowych
}

\begin{abstract}
W artykule przedstawiono wyniki badań laboratoryjnych mających na celu ocenę typu zwilżalności 13 próbek piaskowców kambryjskich. Wstępną charakterystykę przeprowadzono na podstawie pomiarów przepuszczalności względnej, a jej trafność zweryfikowano poprzez ich korelację z kolejno wykonanymi: analizą nasycenia nieredukowalnego dla wody złożowej $\left(S_{w i}\right)$, testem Amotta $\left(I_{w}\right)$, analizą ciśnienia przebicia dla solanki metodą przepływową $\left(P t h_{\text {flow }}\right)$ - współczynnik sczerpania $\left(R F_{\mathrm{I}}\right)$, symulacją procesu nawadniania dla wody złożowej $\left(R F_{\mathrm{II}}\right)$. Wykonano pomiary wielkości kąta kontaktu na granicy solanka-ropa naftowa-skała złożowa dla 3 analizowanych próbek. Podjęto próbę wskazania metody zastępczej dla pomiarów przepuszczalności względnej, która potwierdzi wyznaczony typ zwilżalności ,pierwotnej”.
\end{abstract}

Słowa kluczowe: przepływ płynów złożowych, zwilżalność matrycy skalnej, przepuszczalność względna, współczynnik sczerpania.

\section{Reservoir fluids flow analysis in reservoir rocks}

The paper presents laboratory measurements results, performed in order to evaluate the type of wettability for 13 samples of Cambrian Sandstone. Preliminary characterization was carried out, based on relative permeability measurements which were correlated with additional analysis: irreducible water saturation $\left(S_{w i}\right)$, Amott test, threshold pressure for continuous injection approach $\left(P t h_{\text {flow }}\right)$ - recovery factor $\left(R F_{\mathrm{I}}\right)$, water flooding simulation for brine $\left(R F_{\mathrm{II}}\right)$. Additionally, contact angle measurements for brine/oil/rock system were carried out. An attempt was made to indentify an alternative method for the measurement of relative permeability which will be the most congenial with the designated "primary" wettability type.

Key words: reservoir fluids flow, rock wettability, relative permeability, recovery factor.

\section{Wstęp}

Proces eksploatacji złóż węglowodorów ma na celu osiągnięcie maksymalnego współczynnika sczerpania zasobów przy ekonomicznie opłacalnym systemie prowadzenia prac wydobywczych. Prawidłowa ocena warunków złożowych i odpowiednie zaprojektowanie prac uwarunkowane są jak najlepszym rozpoznaniem złoża przy użyciu dostępnych metod - od badań sejsmicznych poprzez geofizykę otworową po analizę laboratoryjną zwiercin i rdzeni wiertniczych.

Jednym z głównych celów geologii i inżynierii złożowej jest ocena typu zwilżalności matrycy skalnej oraz jego wpływu na rozkład i przepływ płynów złożowych [13]. Badaniami, na podstawie których możliwa jest jego ocena, są analizy petrofizyczne, m.in. pomiar przepuszczalności względnej, wielkości ciśnienia kapilarnego i poziomu nasycenia płynami złożowymi. Obecnie badania laboratoryjne pozwalają na przeprowadzanie wymienionych analiz przy użyciu oryginalnych płynów z zachowaniem warunków złożowych, co w znaczący sposób podnosi wiarygodność otrzymanych wyników i zapewnia ich zgodność ze stanem rzeczywistym.

Eksploatacja złóż ropy i gazu jest racjonalna i efektywna szczególnie wówczas, gdy wdrożone zostaną odpowiednie metody wspomagania wydobycia, w tym tzw. metody wtórne (zatłaczanie wody - nawadnianie) i metody trzecie (m.in. zabiegi mikrobiologiczne, zatłaczanie $\mathrm{CO}_{2}$, metody termiczne). W przypadku złóż ropy naftowej zabiegi te mogą pozwolić nawet na dwukrotne zwiększenie ilości wyeksploatowanej ropy. 
Nie bez znaczenia pozostaje jednak fakt, że efekty zastosowania tych metod ujawniają się dopiero po upływie dłuższego czasu. Ważne jest zatem odpowiednio wczesne rozpoznanie stopnia możliwości poprawy sczerpania zasobów złoża w celu poprawnego zaprojektowania prac i wprowadzenia metod wspomagających wydobycie w odpowiednim czasie $[2,11,12]$.

\section{Zwilżalność skał zbiornikowych}

Przepływ dwóch niemieszających się ze sobą faz, rozkład i stopień nasycenia każdą z nich przestrzeni porowej w znacznym stopniu uzależnione są od typu zwilżalności matrycy skalnej [6]. Właściwość ta definiowana jest jako zdolność medium do rozprzestrzeniania się na (przylegania do) powierzchni skały w obecności innej, niemieszającej się z nią fazy. W układzie skała-ropa-solanka zwilżalność to miara preferencji skały zbiornikowej w stosunku do ropy lub solanki. Wykazano, że zmiany zwilżalności wpływają na wyniki pomiarów większości badań laboratoryjnych, takich jak pomiar właściwości elektrycznych, ciśnień kapilarnych, przepuszczalności względnej, symulacji zabiegów nawadniania $\mathrm{i}$ innych $[3,6,14]$.
A

układ wodozwilżalny

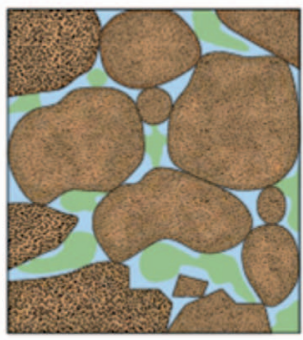

\section{B}

$$
\text { układ o zwilżalności }
$$
mieszanej

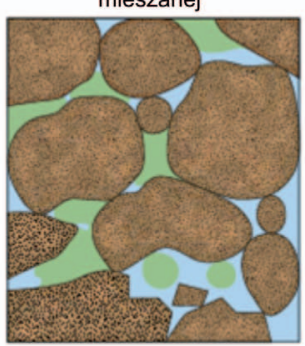

\section{C} układ ropozwilżalny

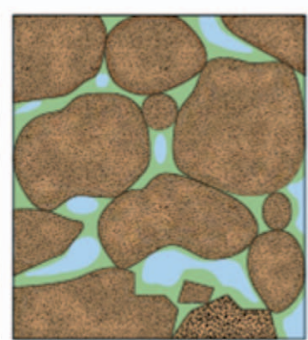

$\square$ ropa $\square$ woda złożowa $\square$ matryca skalna

Rys. 1. Typy zwilżalności matrycy skalnej [1]

W przypadku gdy skała wykazuje tendencję do kontaktu z solanką na większości swojej powierzchni, mamy do czynienia z jej wodozwilżalnością - faza zwilżająca wypełnia prawie $\mathrm{w}$ całości pory skalne, a faza niezwilżająca znajduje się tylko w ich centralnej części (rysunek 1A). Sytuacja jest odwrotna w przypadku ropy jako cieczy zwilżającej - matryca skalna charakteryzuje się ropozwilżalnością - większość porów zajęta jest przez ropę, woda zajmuje niewielkie objętości w ich środkowych partiach (rysunek 1C). Jeżeli skała nie wykazuje preferencji dla którejś z cieczy, żadna z faz nie pokrywa ścian porów w dominującym stopniu, mamy do czynienia ze zwilżalnością mieszaną (rysunek 1B) [3].

Najczęściej stosowaną wtórną metodą eksploatacji złóż ropy naftowej jest nawadnianie oryginalną wodą złożową solanka zatłaczana jest do złoża, powodując wzrost ciśnienia złożowego, czego końcowym efektem jest zwiększenie współczynnika sczerpania. Zakładając, że w początkowym etapie eksploatacji do otworów produkcyjnych dopływa wy- łącznie ropa, moment, w którym następuje przebicie wody, charakteryzuje się powolnym spadkiem ilości dopływającej ropy i zwiększającym się wykładnikiem wodnym. Proces nawadniania powinien być kontynuowany aż do momentu, gdy dalsze prowadzenie eksploatacji jest nieopłacalne ze względu na zbyt duży przypływ solanki złożowej do otworów produkcyjnych [5]. Podczas realizacji procesu nawadniania w systemie wodozwilżalnym faza wodna pokrywa ściany porów i tylko częściowo usuwa ropę z przestrzeni porowej (rysunek 2A). Po przebiciu się fazy wodnej wskaźnik produkcji wody do ropy gwałtownie wzrasta i niewielkie dodatkowe ilości ropy są usuwane z przestrzeni porowej, co jest równoznaczne z końcem ekonomicznie uzasadnionego dalszego prowadzenia procesu nawadniania (eksploatacji z danego otworu w skali złoża). W systemie ropozwilżalnym w wyniku procesu nawadniania moment przebicia fazy wodnej następuje stosunkowo wcześnie, a większość ropy usuwana jest w późniejszym czasie (rysunek 2B). Nawadnianie w tym przypadku jest mniej efektywne, ponieważ większe ilości wody należy zatłoczyć do próbki/złoża w celu uzyskania takiej samej produkcji ropy jak w systemie wodozwilżalnym [5].

A
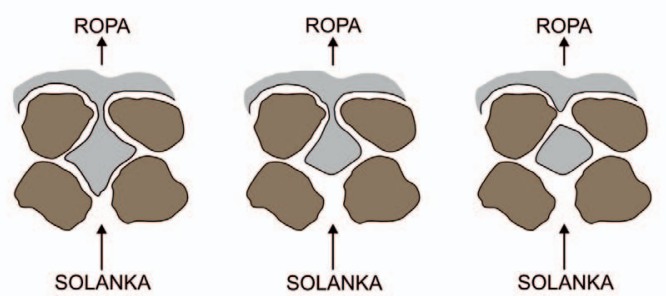

B
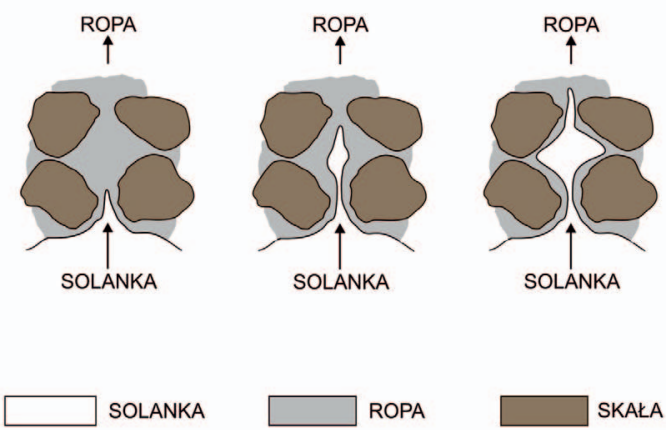

Rys. 2. Proces nawadniania przestrzeni porowej skały dla systemu wodozwilżalnego (A) oraz dla systemu ropozwilżalnego (B) [4] 


\section{Badania laboratoryjne}

Spośród wykonanych analiz (tablica 1) do grupy metod ilościowych zaliczyć należy pomiar kąta kontaktu na granicy solanka-ropa naftowa-skała złożowa [3, 7] oraz test Amotta [3]. Metodami jakościowymi są: pomiar przepuszczalności względnej $[4,8,9,10]$ i stosunek przepuszczalności absolutnej do wielkości nasycenia nieredukowalnego $\left(S_{w i}\right)[3]$.

Wyselekcjonowane próbki typu „plug” (rdzeń o średnicy 2,54 cm, długości około $4 \mathrm{~cm}$ ) poddano kolejno dwóm grupom analiz. W pierwszym zestawie badań wyznaczono poziom nasycenia nieredukowalnego dla wody złożowej $\left(S_{w i 1}\right)$, określono wielkości przepuszczalności względnej płynów złożowych (ropa naftowa, solanka) i wykonano test Amotta $\left(I_{w}\right)$. W drugiej części po oczyszczeniu próbek z płynów złożowych przeprowadzono ponowny pomiar nasycenia nieredukowalnego $\left(S_{\text {will }}\right)$, określono poziom minimalnego ciśnienia wymaganego do przepływu ropy naftowej przez przestrzeń porową skały - ciśnienie przebicia dla solanki metodą przepływową $\left(P t_{\text {flow }}\right)[7,10]$ - wyznaczając współczynnik sczerpania „złoża-próbki” - $\left(R F_{\mathrm{I}}\right)$. Następnie wykonano symulację procesu nawadniania przy użyciu oryginalnej wody złożowej $\left(R F_{\text {II }}\right)$ [11]. Dodatkowo dokonano pomiarów wielkości kąta kontaktu na granicy solanka-ropa naftowa-skała złożowa dla 3 wybranych próbek.

Na podstawie otrzymanych wyników podjęto próbę oceny typu zwilżalności matrycy skalnej. Zestawienie rezultatów umożliwiło weryfikację trafności „pierwotnego” wyboru typu zwilżalności oraz ustalenie stopnia zgodności pomiędzy przeprowadzonymi analizami. Podjęto próbę wskazania metody zastępczej dla pomiarów przepuszczalności względnej, która potwierdzi wyznaczony typ zwilżalności „pierwotnej”.

\section{Interpretacja wyników}

Charakterystyka przepływu płynów złożowych wykonana została na podstawie wyników analiz laboratoryjnych próbek pochodzących z utworów piaskowców kambryjskich. Wstępną selekcję przeprowadzono, opierając się na pomiarach przepuszczalności absolutnej dla gazu (azot techniczny) oraz wynikach badań porozymetrycznych (tablica 1).

Spośród zastosowanych metod za najpewniejszy i za najbardziej kompleksowy przyjęto pomiar przepuszczalności względnej, na podstawie którego określono wstępne typy zwilżalności analizowanych próbek (tablica 1) i do nich porównywano kolejne wyniki.

\section{Nasycenie nieredukowalne $\left(S_{w i}\right)$ a przepuszczalność absolutna $\left(K_{\text {abs }}\right)$}

Jednym z jakościowych zestawień, obrazującym zmiany w procentowym udziale mediów złożowych wypełniających przestrzeń porową próbki spowodowane zmiennością zwilżalności matrycy skalnej, jest zależność wielkości przepuszczalności absolutnej $\left(K_{a b s}\right)$ od nasycenia nieredukowalnego wodą złożową $\left(S_{w i}\right)$. Jest to metoda statystyczna, wymagająca jak największej liczby pomiarów, która jedynie w przybliżonym stopniu może wskazać typ zwilżalności analizowanych próbek. Na tej podstawie przyjmuje się, że silnie ropozwilżalne próbki odznaczają się niskimi oraz niewielkimi zmianami wartości nieredukowalnego nasycenia wodą złożową przy wysokich wynikach pomiarów przepuszczalności absolutnych. W przypadku skał silnie wodozwilżalnych wyniki odznaczają się niższymi wartościami $K_{a b s}$ przy jednocześnie wyższych wartościach i większym zakresie zmienności $S_{w i}[3]$.
Otrzymane zależności (rysunki 3 i 4) nie wskazują w dominujący sposób na typ zwilżalności analizowanych próbek. W obu przypadkach odznaczającą się grupą (I) są próbki

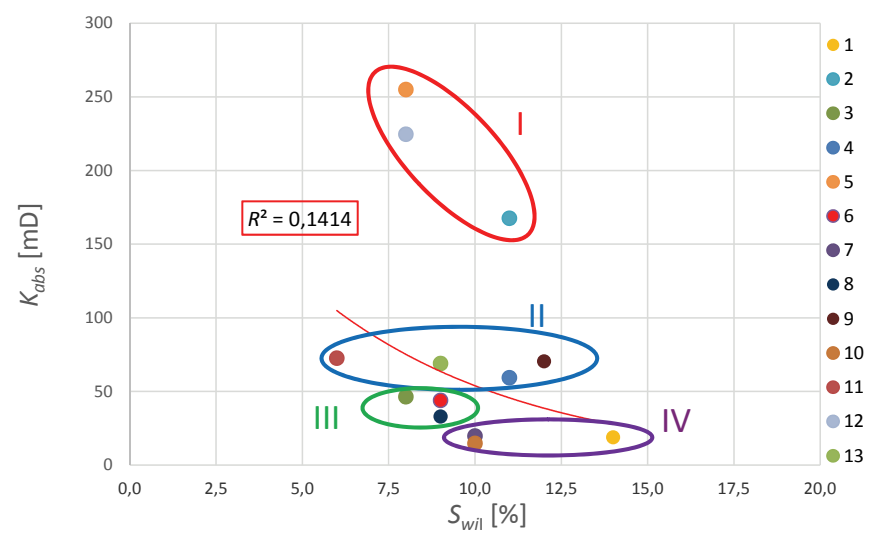

Rys. 3. Zależność wartości nasycenia nieredukowalnego dla solanki $\left(S_{\text {wil }}\right)$ od przepuszczalności absolutnej dla gazu $\left(K_{a b s}\right)$

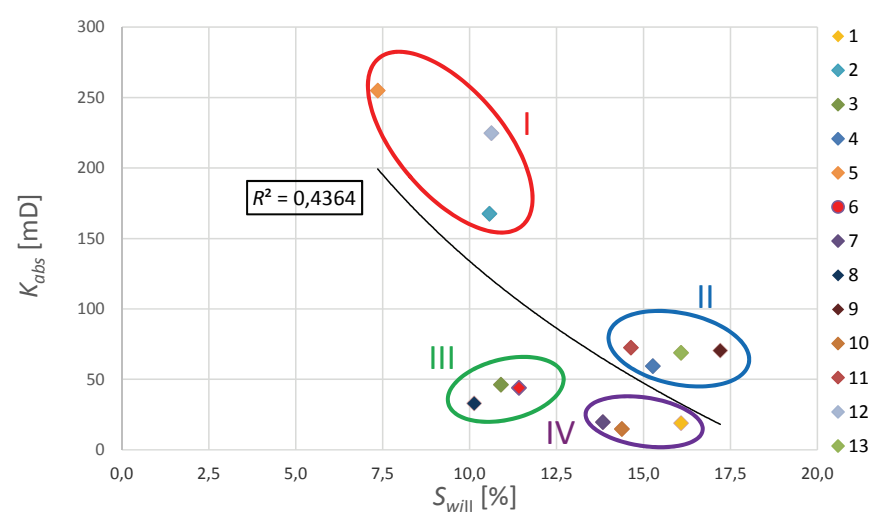

Rys. 4. Zależność wartości nasycenia nieredukowalnego dla solanki $\left(S_{w i I}\right)$ od przepuszczalności absolutnej dla gazu $\left(K_{a b s}\right)$ 
nr 2, 5 i 12, których wyniki charakteryzują się wysokimi wartościami przepuszczalności absolutnej przy niższych wartościach nasycenia nieredukowalnego, co może świadczyć o ich ropozwilżalności. Pozostałe próbki wskazują tendencję w stronę zwilżalności mieszanej lub wodozwilżalności. Kolejne wyznaczone grupy na obydwu wykresach różnią

\begin{tabular}{|c|c|c|c|c|c|c|c|c|c|c|c|c|c|}
\hline 슬 & 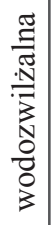 & 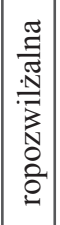 & 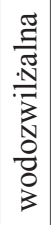 & 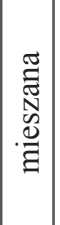 & 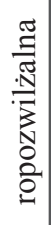 & 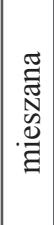 & 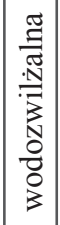 & 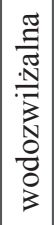 & 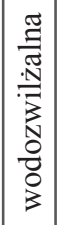 & 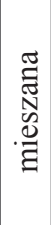 & 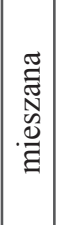 & 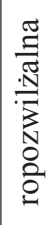 & 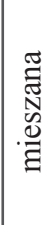 \\
\hline 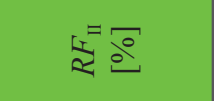 & $\begin{array}{l}n \\
6 \\
\dot{t}\end{array}$ & $\begin{array}{l}0 \\
\infty \\
\approx \\
=\end{array}$ & $\begin{array}{l}\stackrel{m}{q} \\
\stackrel{d}{m}\end{array}$ & $\begin{array}{l}8 \\
8 \\
0 \\
\text { in }\end{array}$ & $\stackrel{n}{\underline{0}}$ & $\begin{array}{l}8 \\
2 \\
i\end{array}$ & $\left|\begin{array}{c}8 \\
8 \\
0 \\
\tilde{n}\end{array}\right|$ & 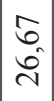 & 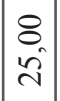 & $\begin{array}{l}8 \\
\text { in } \\
\text { ñ }\end{array}$ & $\begin{array}{c}\infty \\
\infty \\
\tilde{n}\end{array}$ & 8 & $\begin{array}{l}m \\
m \\
m \\
m\end{array}$ \\
\hline$\stackrel{5}{2}$ & $\hat{\hat{n}}$ & 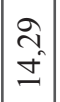 & $\begin{array}{l}\tilde{0} \\
\hat{N} \\
\hat{N}\end{array}$ & $\begin{array}{l}8 \\
0 \\
0 \\
-\end{array}$ & $\begin{array}{l}8 \\
\text { d } \\
\text { in }\end{array}$ & $\begin{array}{l}\text { in } \\
\text { in }\end{array}$ & 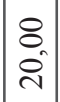 & $\begin{array}{l}m \\
m \\
m \\
m\end{array}$ & $\begin{array}{l}n \\
r \\
\infty\end{array}$ & $\begin{array}{l}8 \\
\text { ¿ } \\
\infty \\
\text { సे }\end{array}$ & $\begin{array}{c}\infty \\
\infty \\
\infty\end{array}$ & 음 & $\frac{\infty}{\sim}$ \\
\hline & $\begin{array}{l}\hat{0} \\
\hat{i}\end{array}$ & $\begin{array}{c}\hat{\sim} \\
\hat{1}\end{array}$ & $\begin{array}{l}\infty \\
0 \\
0 \\
0\end{array}$ & 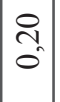 & $\begin{array}{l}\hat{q}_{0} \\
\hat{q}^{\prime}\end{array}$ & $\begin{array}{l}0 \\
0 \\
0 \\
1\end{array}$ & $=$ & $\begin{array}{l}0 \\
0 \\
0 \\
1\end{array}$ & $\begin{array}{c}Z \\
\dot{0}\end{array}$ & to. & $\begin{array}{l}1 \\
0\end{array}$ & $\begin{array}{l}n \\
n \\
0 \\
1\end{array}$ & $\stackrel{0}{0}$ \\
\hline$\frac{5}{2}$ & 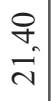 & $\mid \begin{array}{c}\stackrel{P}{+} \\
\tilde{q}\end{array}$ & $\begin{array}{l}8 \\
\stackrel{n}{2}\end{array}$ & $\begin{array}{l}0 \\
0 \\
\end{array}$ & $\begin{array}{l}8 \\
8 \\
i\end{array}$ & $\begin{array}{l}8 \\
8 \\
0 \\
0\end{array}$ & $\left|\begin{array}{l}8 \\
\Xi \\
\dot{J}\end{array}\right|$ & $\begin{array}{l}0 \\
0 \\
0\end{array}$ & $\begin{array}{l}0 \\
\mathfrak{q}_{0} \\
0\end{array}$ & $\begin{array}{l}8 \\
\stackrel{8}{0} \\
\infty\end{array}$ & 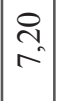 & $\begin{array}{l}8 \\
\infty \\
i\end{array}$ & $\stackrel{\infty}{=}$ \\
\hline & $\begin{array}{l}1 \\
\infty \\
0 \\
0\end{array}$ & $\begin{array}{l}0 \\
\stackrel{n}{n} \\
0\end{array}$ & $\begin{array}{l}\bar{\infty} \\
0 \\
0\end{array}$ & $\begin{array}{c}\tilde{f} \\
\tilde{\sigma}\end{array}$ & $\tilde{F}_{\tilde{\sigma}}$ & $\begin{array}{l}\infty \\
\infty \\
0\end{array}$ & $\begin{array}{l}\tilde{\sigma} \\
0 \\
0\end{array}$ & $\begin{array}{l}\infty \\
\infty \\
0 \\
0\end{array}$ & $\begin{array}{c}\bar{\infty} \\
0 \\
0\end{array}$ & $\begin{array}{l}0 \\
\infty \\
0 \\
0\end{array}$ & $\overrightarrow{0}$ & $\underset{\sigma}{a}$ & $\begin{array}{l}\infty \\
0\end{array}$ \\
\hline & $\frac{a}{0}$ & $\left|\begin{array}{l}n \\
n \\
0\end{array}\right|$ & $\begin{array}{l}n \\
\tilde{\sigma} \\
0\end{array}$ & $\begin{array}{l}\bar{n} \\
0\end{array}$ & $\begin{array}{l}1 \\
n \\
0 \\
0\end{array}$ & $\begin{array}{l}\infty \\
\infty \\
0 \\
0\end{array}$ & $\begin{array}{c}\infty \\
\sim \\
0 \\
0\end{array}$ & $\begin{array}{l}\hat{\imath} \\
0 \\
0\end{array}$ & $\begin{array}{l}n \\
\tilde{n} \\
0\end{array}$ & $\vec{n}$ & $\begin{array}{l}N \\
\tilde{n} \\
0\end{array}$ & $\overline{0}$ & $\hat{n}$ \\
\hline & $\overrightarrow{0}$ & $\begin{array}{l}0 \\
0 \\
0\end{array} \mid$ & $\hat{\sigma}$ & $\begin{array}{l}n \\
n \\
n\end{array}$ & $\stackrel{\sigma_{n}}{\sim}$ & $\stackrel{\sigma_{0}}{=}$ & $\begin{array}{l}\infty \\
\tilde{n}^{n}\end{array}$ & $\overrightarrow{0}$ & $\stackrel{N}{=}$ & $\stackrel{\nabla}{ \pm}$ & $\begin{array}{l}0 \\
\pm \\
\pm\end{array}$ & 0 & $\overrightarrow{0}$ \\
\hline$\omega^{\circ}$ & $\begin{array}{l}0 \\
\pm \\
\pm\end{array}$ & $\stackrel{0}{=}$ & $\begin{array}{c}0 \\
\infty\end{array}$ & $\begin{array}{l}0 \\
=\end{array}$ & $\begin{array}{c}0 \\
\infty\end{array}$ & O. & $\begin{array}{l}0 \\
0 \\
0\end{array}$ & $\begin{array}{l}0 \\
a^{n}\end{array}$ & $\begin{array}{l}0 \\
\mathrm{I}\end{array}$ & $\begin{array}{l}0 \\
0 \\
-\end{array}$ & $\begin{array}{l}0 \\
0\end{array}$ & $\begin{array}{l}0 \\
\infty\end{array}$ & O. \\
\hline 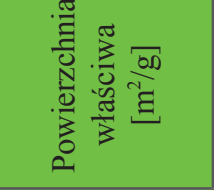 & $\frac{ \pm}{0}$ & $\left|\begin{array}{l}\infty \\
0 \\
0 \\
0\end{array}\right|$ & $\begin{array}{l}n \\
0 \\
0\end{array}$ & $\begin{array}{l}\tau \\
0 \\
0\end{array}$ & $\frac{m}{0}$ & $\begin{array}{l}2 \\
0 \\
0\end{array}$ & $\frac{m}{0}$ & $=$ & $\mid \begin{array}{l}\infty \\
0 \\
0\end{array}$ & $\left|\begin{array}{l}0 \\
0 \\
0\end{array}\right|$ & $\begin{array}{l} \pm \\
0 \\
0\end{array}$ & $\frac{m}{0}$ & $\stackrel{2}{\sim}$ \\
\hline 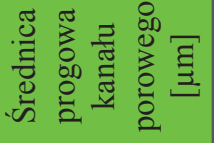 & $a$ & $\stackrel{\ominus}{\sim}$ & $\stackrel{\overbrace{}}{\sim}$ & $\stackrel{\ominus}{\sim}$ & $\stackrel{\sim}{\sim}$ & ㄱ. & $ㅇ$ & 이 & $\stackrel{\overbrace{}}{\sim}$ & $\stackrel{0}{-}$ & $\stackrel{\sim}{\sim}$ & 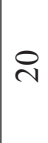 & ㄱ. \\
\hline 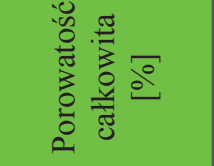 & $\begin{array}{l}\tilde{\sigma} \\
\sim \\
\sim\end{array}$ & $\left|\begin{array}{l}2 \\
\infty \\
n \\
n\end{array}\right|$ & $\begin{array}{c}8 \\
\tilde{n} \\
-1\end{array} \mid$ & $\begin{array}{l}\vec{\infty} \\
0 \\
0\end{array}$ & $\left|\begin{array}{l}\infty \\
\infty \\
0 \\
0\end{array}\right|$ & $\vec{\sim}$ & $\begin{array}{l}\vec{\infty} \\
=\end{array}$ & $\begin{array}{l}\infty \\
n \\
\simeq \\
\simeq\end{array}$ & 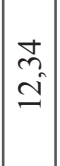 & $\begin{array}{l}0 \\
0 \\
a\end{array}$ & $\left|\begin{array}{l}0 \\
0 \\
0 \\
0\end{array}\right|$ & $\begin{array}{l}\mathcal{N} \\
\infty \\
\simeq \\
\end{array}$ & $\begin{array}{l}n \\
\tilde{n} \\
\cong\end{array}$ \\
\hline$v^{3}$ & $\begin{array}{l}\Re \\
\infty \\
\infty\end{array}$ & $\left|\begin{array}{l}0 \\
\tilde{2} \\
\hat{0} \\
-\end{array}\right|$ & 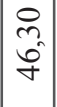 & $\begin{array}{l}\bar{n} \\
\tilde{n}\end{array}$ & $\begin{array}{l}\vec{a} \\
\tilde{v} \\
\tilde{v}\end{array}$ & 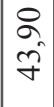 & $\begin{array}{l}8 \\
\mathbb{0} \\
2 \\
=\end{array}$ & $\begin{array}{l}\bar{\sigma} \\
m \\
m\end{array}$ & $\begin{array}{l}\stackrel{0}{2} \\
\stackrel{n}{2} \\
\stackrel{2}{2}\end{array}$ & $\begin{array}{l} \pm \\
\pm \\
\Xi\end{array}$ & $\begin{array}{l}8 \\
8 \\
i \\
1\end{array} \mid$ & $\begin{array}{l}\stackrel{R}{2} \\
\stackrel{ \pm}{ \pm}\end{array}$ & $\begin{array}{l}\infty \\
\infty \\
\infty \\
\infty\end{array}$ \\
\hline 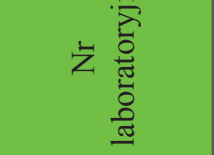 & 辛 & $\begin{array}{l}n \\
\sigma \\
\sigma\end{array}$ & $\begin{array}{l}n \\
n \\
n \\
\infty\end{array}$ & $\begin{array}{l}n \\
0 \\
0 \\
\sigma\end{array} \mid$ & 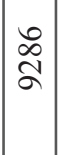 & 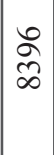 & $\left|\begin{array}{c}0 \\
\infty \\
\infty \\
\infty\end{array}\right|$ & 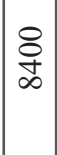 & $\begin{array}{c}\tilde{D} \\
\tilde{\infty}\end{array}$ & $\begin{array}{c}m \\
\tilde{\delta} \\
\infty \\
\infty\end{array}$ & $\begin{array}{l}\bar{m} \\
\tilde{\sigma}\end{array}$ & $\frac{0}{\sigma}$ & $\frac{\nabla}{\sigma}$ \\
\hline$\stackrel{1}{3}$ & $-\dot{-}$ & i & $\dot{m}$ & $\dot{\nabla}$ & $i$ & $0^{\circ}$ & $\therefore$ & $\infty$ & $\sigma^{\circ}$ & $\dot{0}$ & 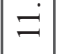 & $\stackrel{I}{ }$ & $\ddot{n}$ \\
\hline
\end{tabular}

się reprezentowanymi wynikami - rożne wartości nasycenia nieredukowalnego dla tych samych przepuszczalności absolutnych. Na rysunku 3 w przypadku wszystkich trzech zbiorów $S_{w i}$ osiąga wartości generalnie niższe i o większym zakresie zmienności niż wyniki $S_{\text {wiI }}$ przedstawione na rysunku 4. Dla zbliżonych wartości przepuszczalności absolutnej poziom nasycenia nieredukowalnego jest znacznie bardziej zróżnicowany.

Uzyskane wyniki nasycenia nieredukowalnego dla solanki $S_{w i I I}$ w większości przypadków są wyższe od $S_{\text {wil }}$, tylko w dwóch (nr 2 i 5) drugi pomiar dał rezultat niższy od pierwotnego (tablica 1). Zaobserwowane różnice mogą być spowodowane różnymi wartościami ciśnień zatłaczanej ropy naftowej (faza wypierająca solankę) podczas przeprowadzania pomiaru. W trakcie wykonywania analizy możliwe jest również usunięcie wraz z wypieraną solanką cząstek materii organicznej lub mniejszych, luźnych ziaren skalnych z przestrzeni porowej próbki, co zmienia objętość porów możliwych do zajęcia przez wodę, a tym samym może wpłynąć na zmianę poziomu nasycenia nieredukowalnego. Alternatywnym wyjaśnieniem tego zjawiska może być również przemieszczanie się cząstek stałych w obrębie przestrzeni porowej próbki i odcięcie części systemu porowego dla przepływu płynów złożowych.

\section{Pomiar przepuszczalności względnej}

Wykonane pomiary przepuszczalności względnej dla układu solanka-ropa stanowiły główną część przedstawionego opracowania. W przypadku skał wodozwilżalnych wartości przepuszczalności względnej dla wody są niższe niż dla ropy naftowej i na odwrót - ośrodek porowaty ropozwilżalny charakteryzuje się wyższymi przepuszczalnościami względnymi dla wody złożowej niż ropy naftowej (tablica 1, kolumny 9 i 10).

Wyniki analizy przepuszczalności względnej dla wody zestawione $\mathrm{z}$ wielkościami nasycenia nieredukowalnego (rysunek 5) wskazują na wzrost objętości fazy wodnej w przestrzeniach porowych próbek w miarę spadku odpowiadających im przepuszczalności względnych. Przyjmując powyżej przedstawione zależności typu zwilżalności matrycy skalnej od wartości $K_{w(w)}$, należy stwierdzić, że im wyższy poziom nasycenia nieredukowalnego dla solanki, tym skała jest bardziej wodozwilżalna.

Przedstawione wyniki pomiarów próbek nr 9, 11 i 13, scharakteryzowanych jako wodozwilżalne (rysunek 6), także potwierdzają tę zależność. Otrzymane wartości dla $K_{w(w)}$ z zakresu od 0,25 do 0,37 wskazują na zajmowanie przez solankę (jako fazę zwilżającą) 


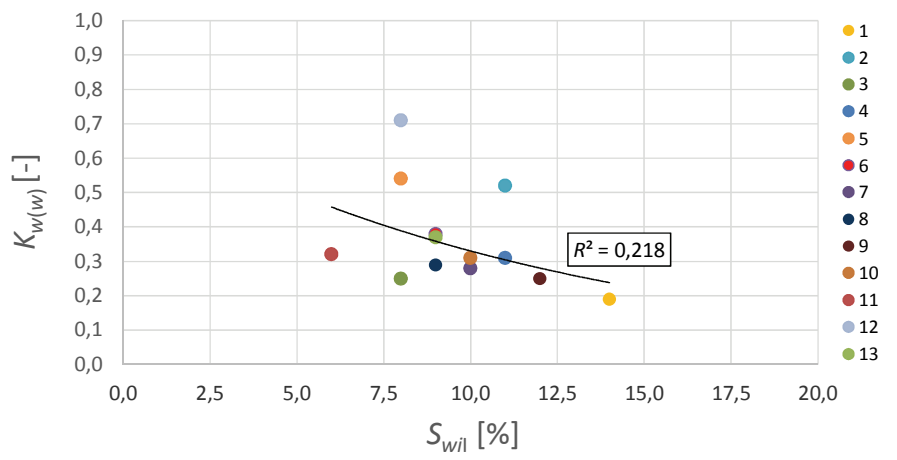

Rys. 5. Zależność przepuszczalności względnej dla wody $\left(K_{w(w)}\right)$ od wartości nasycenia nieredukowalnego dla solanki $\left(S_{w i}\right)$

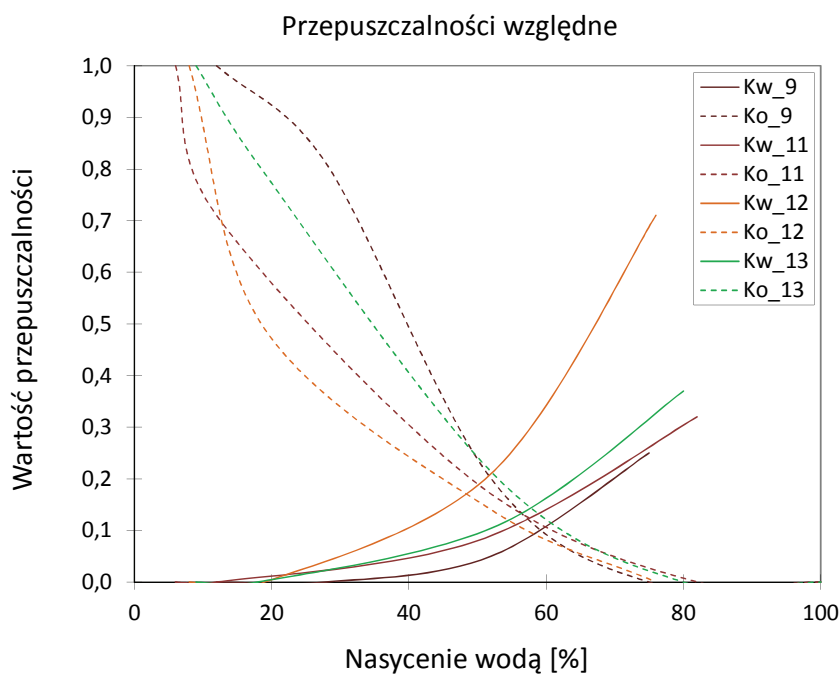

Rys. 6. Krzywe przepuszczalności względnych dla systemu woda-ropa względem wartości nasycenia wodą złożową

mniejszych porów w skali próbki, przy przepływie fazy niezwilżającej (ropa) tylko większymi, głównymi kanałami porowymi. Umieszczone dodatkowo na wykresie krzywe przepuszczalności względnej dla próbki nr 12 (jako próbki ropozwilżalnej) obrazują różnice w kształcie, przebiegu krzywych dla obu płynów złożowych w zależności od zwilżalności matrycy skalnej.

\section{Test Amotta}

Wyniki badań testu Amotta zebrane i porównane z poprzednimi analizami w tablicy 1 generalnie potwierdzają typy zwilżalności analizowanych próbek wyznaczone na podstawie wcześniejszych pomiarów.

Wartości indeksu Amotta-Harveya zestawione z rezultatami pomiarów przepuszczalności względnej dla wody (rysunek 7) wykazują tendencję spadkową (w zakresie od 1 do -1) wraz ze zmniejszaniem się wartości $K_{w(w)}$, gdzie wielkość -1 odpowiada skale silnie wodozwilżalnej. Spośród analizowanych próbek trzy (nr 2, 5, 12), wyznaczone na podstawie pomiaru przepuszczalności względnej, zaliczono do grupy ropozwilżalnej, a wyniki testu Amotta to potwierdzają - otrzy- mane wartości plasują się $\mathrm{w}$ dodatnim zakresie indeksu $I_{w}$. Przyjmuje się, że w przypadku skał wodozwilżalnych wartości przepuszczalności względnej dla solanki jako cieczy zwilżającej typowo mieszczą się w zakresie od 0,2 do 0,3. Uzyskane wyniki kwalifikują do tej grupy 5 próbek, wśród których tylko w 2 przypadkach wartości $I_{w}$ są ujemne. W trzech pozostałych indeks Amotta-Harveya ma niewielkie wartości dodatnie, co może wskazywać na mieszany typ zwilżalności matrycy skalnej. Dla pozostałych próbek wielkości $I_{w}$ pokrywają się z wartościami przepuszczalności względnej dla solanki i klasyfikują je także w grupie zwilżalności mieszanej z tendencją do wodozwilżalności. Zestawienie omawianego parametru z wynikami nasycenia nieredukowalnego dla wody (rysunek 8) wykazuje ich niemalże zerową korelację. W tym przypadku nie jest możliwe potwierdzenie typu zwilżalności (określonego testem Amotta) poziomem nasycenia nieredukowalnego próbki.

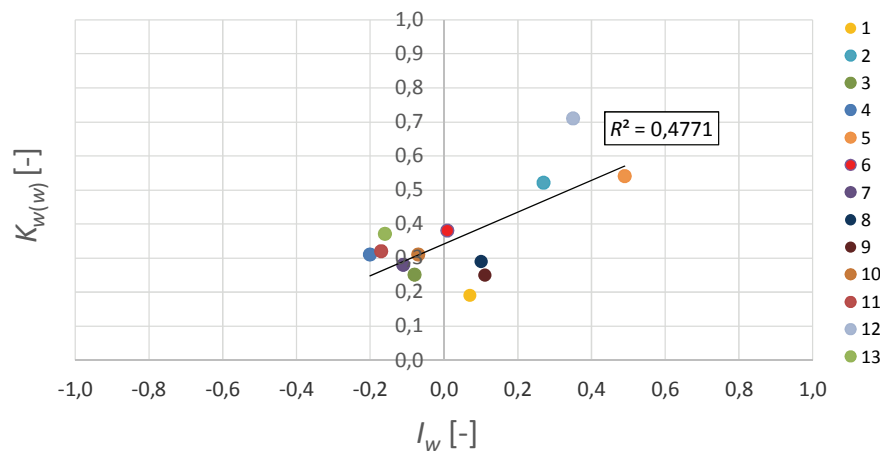

Rys. 7. Zależność wielkości indeksu Amotta-Harveya $\left(I_{w}\right)$ od przepuszczalności względnej dla solanki $\left(K_{w(w)}\right)$

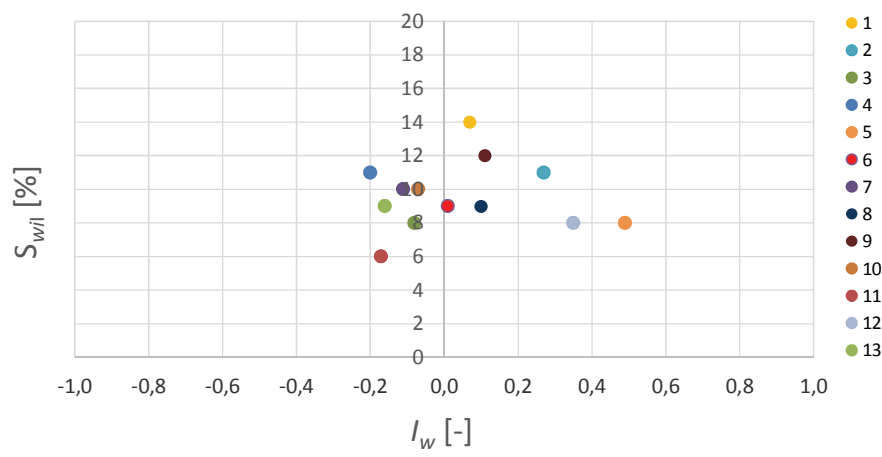

Rys. 8. Zależność wielkości indeksu Amotta-Harveya $\left(I_{w}\right)$ od poziomu nasycenia nieredukowalnego dla solanki $\left(S_{w i}\right)$

\section{Ciśnienie przebicia}

Badanie wielkości ciśnienia przebicia zostało wykonane metodą przepływową w układzie ropa-solanka. Pomiar przeprowadzono na badanych próbkach po wcześniejszym ustaleniu nieredukowalnego nasycenia dla solanki $S_{\text {wiII }}$ (patrz wcześniejsze pomiary) - wyznaczającego maksymalne nasycenie przestrzeni porowej próbki ropą w obecności dwóch 
niemieszających się ze sobą faz. Proces zatłaczania solanki, jako cieczy wypierającej, odbywał się z możliwie najniższym wydatkiem, równym $0,01 \mathrm{~cm}^{3} / \mathrm{min}$, do momentu pojawienia się pierwszej kropli wody złożowej po przeciwległej stronie rdzenia i spadku ciśnienia zatłaczanego medium. Za wartość ciśnienia przebicia przyjmowane było maksymalne ciśnienie zatłaczanej solanki osiągnięte $\mathrm{w}$ trakcie przeprowadzania badania. Wyniki pomiarów zestawiono w tablicy 1 .

Głównym parametrem petrofizycznym mającym największy wpływ na wielkość ciśnienia przebicia jest współczynnik przepuszczalności absolutnej (rysunek 9). Zależność wielkości ciśnienia przebicia względem poziomu nasycenia nieredukowalnego wodą złożową (rysunek 10) jest dość niska, jednak na jej podstawie można przyjąć założenie wzrostu wartości $P$ th $h_{\text {flow }}$ ze wzrostem $S_{\text {will }}$. Dla próbek nr 9, 11 i 13, scharakteryzowanych jako wodozwilżalne, osiągnięte wartości ciśnienia przebicia generalnie pokrywają się z wynikami wcześniejszych pomiarów i potwierdzają prawidłowość otrzymanych rezultatów (rysunek 11). Woda złożowa jako ciecz wypierająca jest również fazą zwilżającą dla analizowanych próbek. W trakcie przepływu przez rdzeń zajmuje w całości lub w przeważającej części objętość mniejszych porów w skali próbki, co przekłada się na wyższe ciśnienie wymagane do wyparcia ropy naftowej. Jako końcowy wniosek z przepro-

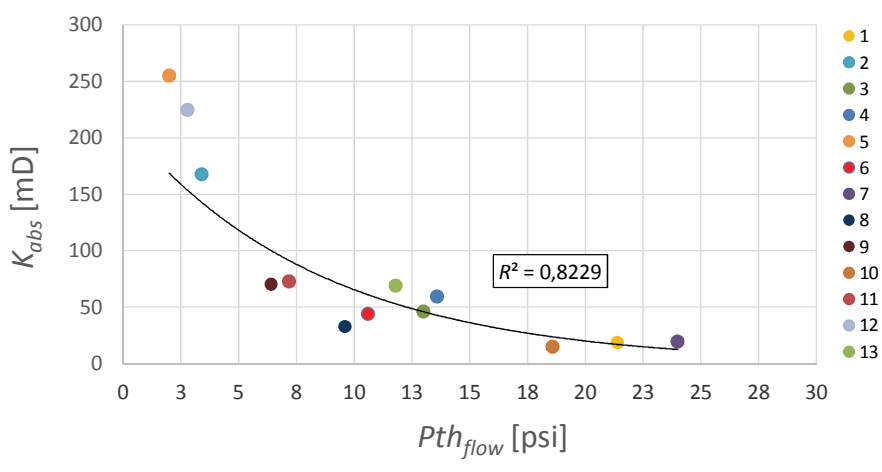

Rys. 9. Zależność poziomu ciśnienia przebicia dla metody przepływowej $\left(P t h_{\text {flow }}\right)$ względem wartości przepuszczalności absolutnej $\left(K_{a b s}\right)$

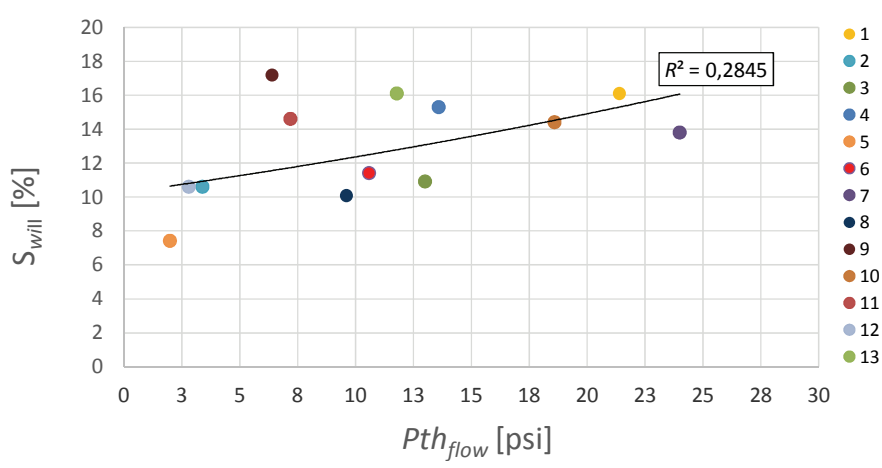

Rys. 10. Zależność poziomu ciśnienia przebicia dla metody przepływowej $\left(P t h_{f l o w}\right)$ względem wartości nasycenia nieredukowalnego dla solanki $\left(S_{\text {wiII }}\right)$ wadzonych pomiarów należy przyjąć zależność tym większego stopnia wodozwilżalności matrycy skalnej, im wyższy jest poziom ciśnienia przebicia dla solanki.

\section{Współczynnik sczerpania i symulacja procesu nawadniania złoża}

Opisany w poprzedniej części pomiar ciśnienia przebicia dla solanki stanowił równocześnie badanie wielkości współczynnika sczerpania ropy naftowej dla analizowanych rdzeni $\left(R F_{\mathrm{I}}\right)$. Objętość wypartej ropy w trakcie procesu wtłaczania wody złożowej do rdzenia odpowiada objętości ropy możliwej do uzyskania w czasie prowadzenia eksploatacji. Przyjęty wydatek wtłaczanej solanki i osiągnięte ciśnienia przebicia określały minimalne ciśnienie złożowe wymagane do wystąpienia dopływu mediów złożowych do odwiertu. Kolejnym przeprowadzonym badaniem była laboratoryjna symulacja nawadniania wodą złożową (wykonana przy 3 różnych wydatkach zatłaczanej cieczy: $0,07 \mathrm{~cm}^{3} / \mathrm{min}, 3,07 \mathrm{~cm}^{3} / \mathrm{min}$ i $6,67 \mathrm{~cm}^{3} / \mathrm{min}$ ), na podstawie którego określono kolejny współczynnik sczerpania $-R F_{\text {II }}$ (tablica 1 ).

Wielkości ciśnienia zatłaczania wody złożowej w czasie symulacji procesu nawadniania przedstawiono na rysunku 11. Podobnie jak w przypadku pomiarów ciśnienia przebicia metodą przepływową główny wpływ na rezultaty miała wielkość przepuszczalności absolutnej $\left(K_{a b s}\right)$. Na wykresie zaobserwować można podział wyników na 3 odrębne grupy, próbki $(\mathrm{nr} 1,7,10)$ o najmniejszej przepuszczalności $(14,47-19,60 \mathrm{mD})$ charakteryzują się znacznie wyższym ciśnieniem zatłaczanej solanki, niż to obserwowano w pozostałych przypadkach. Dla grupy próbek (nr 2, 5, 12) o największych wartościach $K_{a b s}$, zdefiniowanych jako ropozwilżalne, wyniki te nie przekraczają 3,4 psi. Rezultaty pomiarów pozostałych próbek nie wykazują silnej zależności względem $K_{a b s}$, co należy interpretować wpływem typu zwilżalności na otrzymane wyniki. Widać to na przykładzie analiz nr 9, 11 i 13, w których pomimo zbliżonych wartości przepuszczalności absolutnej ciśnienia zatłaczanej solanki (dla $Q=6,67 \mathrm{~cm}^{3} / \mathrm{min}$ ) różnią się znacznie od siebie.

Najważniejszym celem przeprowadzenia symulacji procesu nawadniania było uzyskanie jak największego wskaźnika odropienia złoża (recovery factor). Objętość wypartej ropy otrzymana podczas wykonanej symulacji jednoznacznie wskazuje na zależność wielkości współczynnika sczerpania od typu zwilżalności matrycy skalnej. Z przeprowadzonych badań wynika, że proces nawadniania jest tym bardziej efektywny, im większą wodozwilżalnością odznacza się ośrodek porowaty. Zestawienie współczynników sczerpania $\left(R F_{\mathrm{I}}, R F_{\mathrm{II}}\right) \mathrm{z}$ wynikami nasycenia nieredukowalnego dla solanki $S_{\text {will }}$ (rysunek 12) oraz ciśnienia przebicia $P t h_{\text {flow }}$ (rysunek 13) potwierdza tę zależność. 


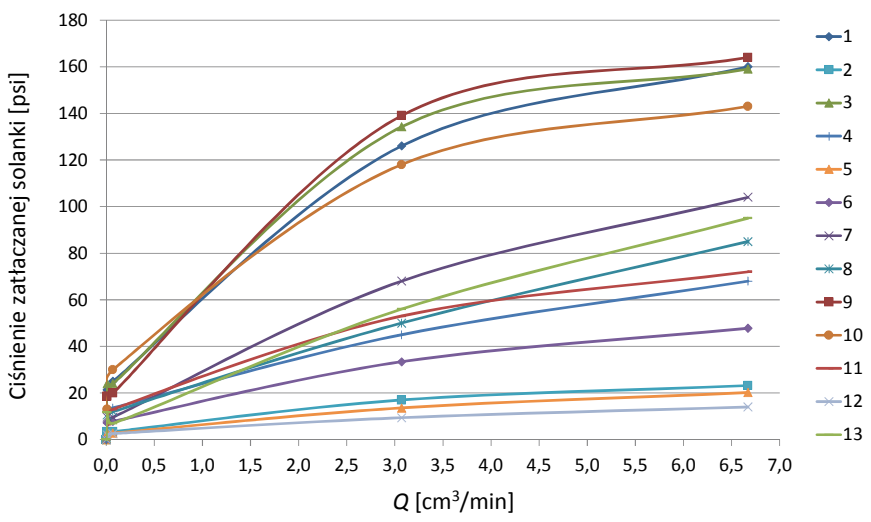

Rys. 11. Wielkość ciśnienia zatłaczania fazy przebijającejwypierającej (solanki) w trakcie pomiaru ciśnienia przebicia oraz symulacji procesu nawadniania

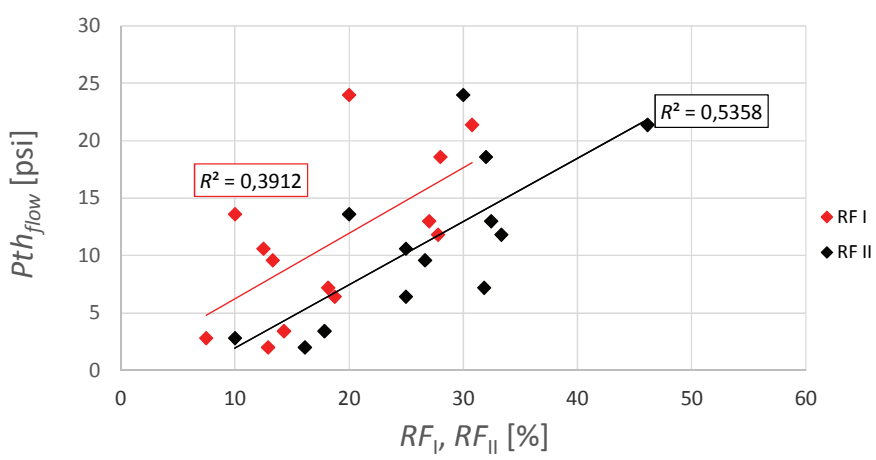

Rys. 13. Zależność wielkości współczynnika sczerpania $\left(R F_{\mathrm{I}}, R F_{\mathrm{II}}\right)$ od poziomu ciśnienia przebicia dla metody przepływowej $\left(\right.$ Pth $\left._{\text {flow }}\right)$

Wyniki pomiarów przepuszczalności względnej i współczynników sczerpania $\left(R F_{\mathrm{I}}, R F_{\mathrm{II}}\right)$ uzyskane zostały w odrębnych grupach pomiarowych, więc ich zestawienie nie jest słuszne z punktu widzenia wiarygodności otrzymanej korelacji. Wydaje się jednak, że wskazany w tym zestawieniu (rysunek 14) silny trend wzrostu $R F_{\mathrm{I}}$ i $R F_{\mathrm{II}}$ wraz ze spadkiem wartości przepuszczalności względnej dla wody jest prawdziwy. Należy założyć, że w sytuacji posiadania danych z badań przepuszczalności względnej otrzymanych $\mathrm{w}$ jednym ciągu pomiarowym z pozostałymi analizami trend uzyskanej korelacji pokrywać się będzie z otrzymanym w tym przypadku.

\section{Pomiar wielkości kąta kontaktu}

W celu weryfikacji wyników oceny typu zwilżalności analizowanych piaskowców kambryjskich wykonane zostały pomiary wielkości kąta kontaktu na granicy solanka-ropa naftowa-skała złożowa dla trzech próbek (tablica 2).

Porównanie wielkości kąta kontaktu i wyznaczonego na jego podstawie typu zwilżalności matrycy skalnej z rodzajem systemu określonego w wyniku przeprowadzonych pomiarów laboratoryjnych wskazuje, że w przypadku wszystkich trzech próbek typy zwil-

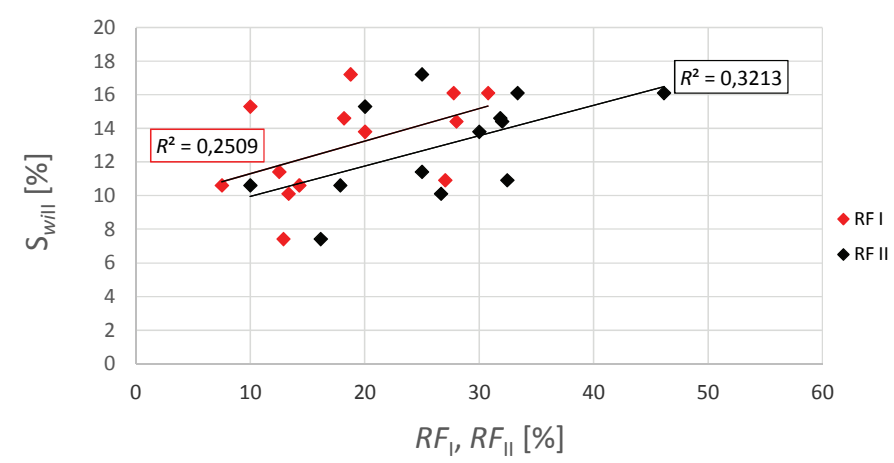

Rys. 12. Zależność wielkości współczynnika sczerpania $\left(R F_{\mathrm{I}}, R F_{\mathrm{II}}\right)$ od wartości nasycenia nieredukowalnego dla solanki $\left(S_{\text {wiII }}\right)$

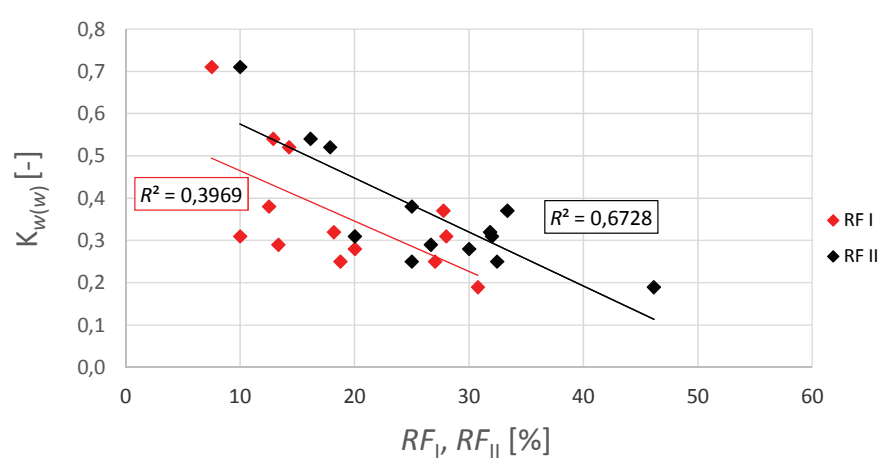

Rys. 14. Zależność wielkości współczynnika sczerpania $\left(R F_{\mathrm{I}}, R F_{\mathrm{II}}\right)$ od wielkości przepuszczalności względnej dla solanki $\left(K_{w(w)}\right)$

żalności z obydwu grup pomiarowych pokrywają się ze sobą. Badanie wykonano poprzez pomiar kąta ,przez” ropę naftową (rysunki 15, 16, 17). Pomiary kąta kontaktu dla próbek nr 4 i 6 wskazują na silne wodozwilżalne właściwości ośrodka skalnego, z kolei próbka nr 5 zakwalifikowana została do typu zwilżalności mieszanej. Głównym pomiarem laboratoryjnym, na podstawie którego określono typ zwilżalności, były wyniki analizy przepuszczalności względnej - odpowiednio dla próbek nr $4\left(K_{w(w)}=0,31 ; K_{w(r)}=0,47\right)$ i $6\left(K_{w(w)}=0,38\right.$; $\left.K_{w(r)}=0,81\right)$ wartości wskazują na system mieszany z tendencją do wodozwilżalnego. Podobnie jest w przypadku próbki nr 5, wartości $\left(K_{w(w)}=0,54 ; K_{w(r)}=0,47\right)$ świadczą o układzie ropozwilżalnym, przy czym niewielka różnica $\mathrm{w}$ tych wynikach tłumaczy kwalifikację próbki do systemu mieszanego na podstawie wielkości zmierzonego kąta kontaktu.

Tablica 2. Zestawienie wyników pomiarów wielkości kąta kontaktu i wyznaczonych typów zwilżalności

\begin{tabular}{|c|c|c|c|}
\hline Lp. & $\begin{array}{c}\text { Średnia wartość } \\
\text { kąta kontaktu } \\
{\left[\alpha^{0}\right]}\end{array}$ & $\begin{array}{c}\text { Typ zwilżalności }- \\
\text { kąt kontaktu }\end{array}$ & $\begin{array}{c}\text { Typ zwilżalności - } \\
\text { pomiary laboratoryjne }\end{array}$ \\
\hline 4. & 157,0 & wodozwilżalny & wodozwilżalny/mieszany \\
\hline 5. & 88,0 & mieszany & ropozwilżalny \\
\hline 6. & 158,5 & wodozwilżalny & wodozwilżalny/mieszany \\
\hline
\end{tabular}




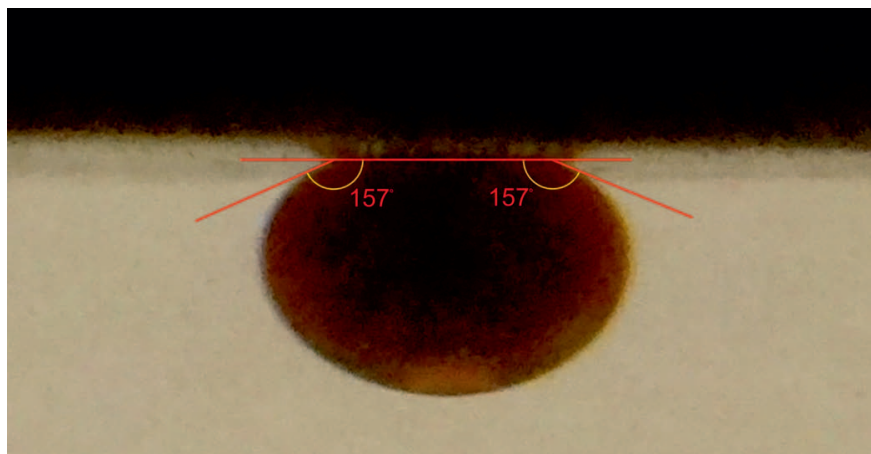

Rys. 15. Kąt kontaktu na granicy solanka-ropa naftowa-skała złożowa dla próbki nr 4

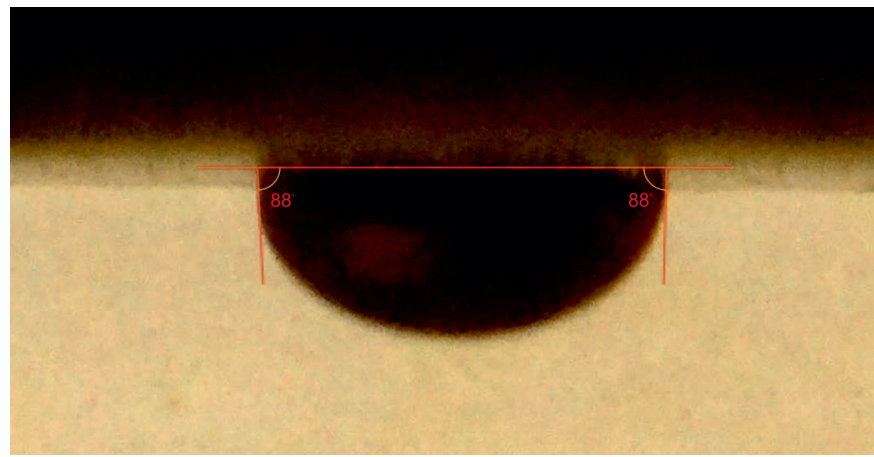

Rys. 16. Kąt kontaktu na granicy solanka-ropa naftowa-skała złożowa dla próbki nr 5

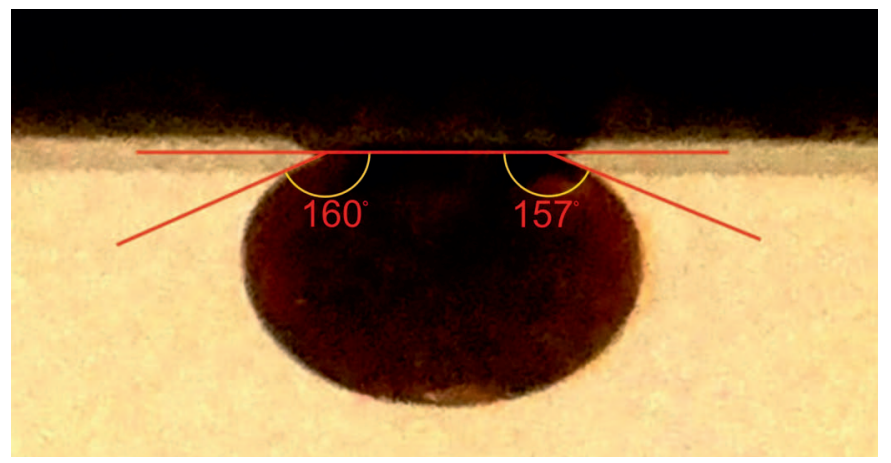

Rys. 17. Kąt kontaktu na granicy solankaropa naftowa-skała złożowa dla próbki nr 6

\section{Podsumowanie i wnioski}

Analiza wykonana na próbkach piaskowców kambryjskich wskazuje na zależność przepływu ropy naftowej i wody złożowej przez przestrzeń porową skał zbiornikowych od typu zwilżalności matrycy skalnej.

Pomiary laboratoryjne przeprowadzono na 13 próbkach, z których 3 scharakteryzowano jako ropozwilżalne ( $\mathrm{nr} 2$, 5,12 ), a w przypadku pozostałych wskazano mieszany typ zwilżalności z przewagą wodozwilżalności dla kilku z nich (tablica 1). Otrzymane wyniki z pozostałych pomiarów laboratoryjnych zestawione $\mathrm{z}$ rezultatami przepuszczalności względnej prowadzą do następujących wniosków:

1. Korelacja wyników przepuszczalności absolutnej z wielkościami nasycenia nieredukowalnego dla solanki w obydwu przypadkach nie daje jednoznacznej odpowiedzi na pytanie o typ zwilżalności analizowanych próbek (rysunki 3 i 4). Metoda ta z powodu zbyt małej liczby prób i zbyt szerokiego zakresu uzyskanych wyników $S_{w i}$ względem zbliżonych wartości $K_{a b s}$ nie jest w stanie wskazać trendu zmienności typu zwilżalności badanych próbek.

2. Zestawienie wyznaczonego nasycenia nieredukowalnego z rezultatami pomiarów przepuszczalności względnej dla wody (rysunek 5) świadczy o wzroście $S_{w i \mathrm{I}}$ wraz ze spadkiem wartości $K_{w(w)}$. Na tej podstawie należy wysunąć wniosek, że im wyższy poziom nasycenia nieredukowalnego dla solanki, tym skała jest bardziej wodozwilżalna.
3. Otrzymane wartości indeksu Amotta-Harveya $\left(I_{w}\right)$ dobrze korelują się z wynikami przepuszczalności względnej dla solanki (rysunek 7). Wskazuje to na poprawność interpretacji wielkości przepływu niemieszających się ze sobą faz względem siebie.

4. Pomiar ciśnienia przebicia wody złożowej przez przestrzeń porową skały zajętą przez solankę $\left(S_{\text {wiII }}\right)$ i ropę naftową prowadzi do stwierdzenia o wzrastającej wodozwilżalności matrycy skalnej wraz ze wzrostem poziomu ciśnienia przebicia (rysunek 10).

5. Zilustrowany na rysunku 11 przebieg krzywych ciśnień zatłaczanej solanki w trakcie pomiaru ciśnienia przebicia oraz symulacji procesu nawadniania wskazuje przede wszystkim na zależność otrzymanych wyników od wielkości przepuszczalności absolutnej. Dla próbek z podobnego zakresu $K_{a b s}$ (np. nr 9, 11, 13) wielkości otrzymanych ciśnień różnią się znacznie od siebie, co wskazuje na wpływ poziomu nasycenia nieredukowalnego na ciśnienie przepływu solanki (rysunek 10), a tym samym potwierdza wzrost wodozwilżalności próbki wraz ze wzrostem poziomu $S_{w i}$.

6. Przeprowadzona symulacja procesu nawadniania wodą złożową świadczy o zależności wielkości współczynnika sczerpania od stopnia wodozwilżalności matrycy skalnej (rysunki 12, 13, 14). Z analizy tych wykresów wraz ze wskazanymi wcześniej zależnościami (punkty 2 i 4) 
wynika, że proces nawadniania jest tym bardziej efektywny, im większą wodozwilżalnością odznacza się ośrodek porowaty.

7. Przedstawione na rysunkach 15, 16 i 17 wielkości kąta kontaktu na granicy solanka-ropa naftowa-skała złożowa weryfikują trafność wyznaczonych typów zwilżalności zarówno na podstawie pomiarów przepuszczalności względnej, jak i pozostałych analiz.

8. Przyjęcie wyników pomiarów przepuszczalności względnej jako najpewniejszej analizy dla oceny typu zwilżalności badanych skał zbiornikowych wydaje się właściwe $-\mathrm{z}$ powodu braku jednoznacznej alternatywy ze stro- ny „dodatkowo” przeprowadzonych pomiarów. Spowodowane jest to zbyt wysoką zmiennością otrzymanych wyników przy jednocześnie niewystarczającej liczbie prób dla celów analizy statystycznej. Pomiary te mogą stanowić jedynie wstęp do dokładniejszej analizy systemu zwilżalności matrycy skalnej lub pełnić rolę weryfikatora głównych pomiarów.

9. Zasadna wydaje się kontynuacja prowadzonych badań i ich rozszerzenie na większą liczbę prób, co pozwoli na przeprowadzenie pełnej analizy statystycznej oraz na ocenę zgodności otrzymanych rezultatów z dotychczasowymi wynikami.

Prosimy cytować jako: Nafta-Gaz 2016, nr 8, s. 610-618, DOI: 10.18668/NG.2016.08.04

Artykuł nadesłano do Redakcji 17.02.2016 r. Zatwierdzono do druku 8.04.2016 r.

Artykuł powstał na podstawie pracy statutowej pt. Analiza przepływu płynów złożowych w skałach zbiornikowych - praca INiG - PIB na zlecenie MNiSW; nr zlecenia: 72/SI, nr archiwalny: SI-4101-72/15.

\section{Literatura}

[1] Abdallah W. et al.: Fundamentals of Wettability. Oilfield Review 2007, vol. 19, no. 2, s. 44-61.

[2] Alklih M. Y., Ghosh B., Al-Shalabi E. W.: A Novel Method for Improving Water Injectivity in Tight Sandstone Reservoirs. Journal of Petroleum Engineering 2014, article ID 864624, s. $1-7$.

[3] Anderson W. G.: Wettability Literature Survey - Part 2: Wettability Measurements. Journal of Petroleum Technology 1986, vol. 38, no. 11, s. 1246-1262.

[4] Anderson W. G.: Wettability Literature Survey - Part 5: The Effects of Wettability on Relative Permeability. Journal of Petroleum Technology 1987, vol. 39, no. 11, s. 1453-1468.

[5] Anderson W. G.: Wettability Literature Survey - Part 6: The Effects of Wettability on Waterflooding. Journal of Petroleum Technology 1987, vol. 39, no. 12, s. 1605-1622.

[6] Bikkina P., Wan J., Kim Y., Kneafsey T. J., Tokunaga T. K.: Influence of Wettability and Permeability Heterogeneity on Miscible $\mathrm{CO}_{2}$ Flooding Efficiency. Fuel 2016, vol. 166, s. 219-226.

[7] Hildenbrand A., Schlömer S., Krooss B. M.: Gas breakthrough experiments on fine-grained sedimentary rocks. Geofluids 2002, vol. 2, no. 1, s. 3-23.

[8] Kruczek J., Such P. (red.): Metodyka pomiaru i interpretacja krzywych przeptywów fazowych skat zbiornikowych dla ropy naftowej i gazu ziemnego. Prace Instytutu Górnictwa Naftowego i Gazownictwa 1995, nr 86, Kraków.

[9] Kruczek J., Such P.: Pomiary przepuszczalności fazowej i matematyczna ekstrapolacja otrzymanych wyników. Przegląd Geologiczny 1995, vol. 43, nr 4, s. 291-294.
[10] Li S., Dong M., Li Z., Huang S., Qing H., Nickel E.: Gas breakthrough pressure for hydrocarbon reservoir seal rocks: implications for the security of long-term $\mathrm{CO}_{2}$ storage in the Weyburn field. Geofluids 2005, vol. 5, no. 4, s. 326-334.

[11] Lubaś J.: O potrzebie bardziej dynamicznego wdrażania metod wspomagania wydobycia ropy naftowej z krajowych złóż. Nafta-Gaz 2013, nr 10, s. 744-750.

[12] Lubaś J., Szott W., Dziadkiewicz M.: Analiza możliwości zwiększenia stopnia sczerpania zasobów złóż ropy naftowej w Polsce. Nafta-Gaz 2012, nr 8, s. 481-489.

[13] Zhao X., Blunt M. J., Yao J.: Pore-scale modeling: Effects of wettability on waterflood oil recovery. Journal of Petroleum Science and Engineering 2010, vol. 71, no. 3-4, s. 169-178.

[14] Zhou X., Morrow N. R., Ma S.: Interrelationship of Wettability, Initial Water Saturation, Aging Time and Oil Recovery by Spontaneous Imbibition and Waterflooding. SPE Journal 2000, vol. 5, no. 2, s. 199-207.

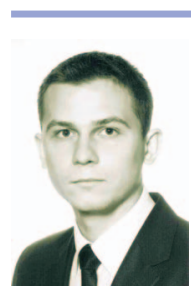

Mgr inż. Marcin MAJKRZAK

Asystent w Zakładzie Inżynierii Naftowej.

Instytut Nafty i Gazu - Państwowy Instytut Badawczy ul. Lubicz 25 A

31-503 Kraków

E-mail: marcin.majkrzak@inig.pl 